\title{
Physico-chemical properties of excavated plastic from landfill mining and current recycling routes
}

L. Canopoli ${ }^{1}$, B. Fidalgo ${ }^{1}$, F. Coulon ${ }^{1}$, S.T. Wagland ${ }^{1 *}$

${ }^{1}$ School of Water, Energy and Environment, Cranfield University, Cranfield, Bedfordshire, MK43 0AL, UK

* Corresponding author: s.t.wagland@ cranfield.ac.uk

\begin{abstract}
:
In Europe over 5.25 billion tonnes of waste has been landfilled between 1995 and 2015. Among this large amount of waste, plastic represents typically 5-25 wt \% which is significant and has the potential to be recycled and reintroduced into the circular economy. To date there is still however little information available of the opportunities and challenges in recovering plastics from landfill sites. In this review, the impacts of landfill chemistry on the degradation and/or contamination of excavated plastic waste are analysed. The feasibility of using excavated plastic waste as feedstock for upcycling to valuable chemicals or liquid fuels through thermochemical conversion is also critically discussed. The limited degradation that is experienced by many plastics in landfills (> 20 years) which guarantee that large amount is still available is largely due to thermooxidative degradation and the anaerobic conditions. However, excavated plastic waste cannot be conventionally recycled due to high level of ash, impurities and heavy metals. Recent studies demonstrated that pyrolysis offers a cost effective alternative option to conventional recycling. The produced pyrolysis oil is expected to have similar characteristics to petroleum diesel oil. The production of valuable product
\end{abstract}


from excavated plastic waste will also increase the feasibility of enhanced landfill mining

projects. However, further studies are needed to investigate the uncertainties about the contamination level and degradation of excavated plastic waste and address their viability for being processed through pyrolysis.

Keywords: Enhanced landfill mining; recycling; excavated plastics; pyrolysis.

Abbreviations: ABS, acrylonitrile-butadiene-styrene; APCr, air pollution control residues; BOD, biological oxygen demand; BPA, bisphenol A; COD, chemical oxygen demand; DEHP, diethyl-hexyl phthalate; DMP, dimethyl phthalate; DoU, degree of unsaturation; DTG, differential thermogravimetric; $\mathrm{E}_{\mathrm{a}}$, activation energy; ELFM, enhanced landfill mining; FCC, fluid catalytic cracking; GC-MS, gas chromatography-mass spectrometry; GCV, gross calorific value; HDPE, high-density polyethylene; HOCs, hydrophobic organic contaminants; IW, industrial waste; LDPE, low-density polyethylene; $\mathrm{M}_{\mathrm{n}}$, number average of molecular weight; MBT, mechanical biological treatment; MSW, municipal solid waste; $\mathrm{NCV}$, net calorific value; NP, nonylphenols; PA, polyamide; PAHs, polycyclic aromatic hydrocarbons; PC, polycarbonate; PCDFs, polychlorinated dibenzofurans; PE, polyethylene; PET, polyethylene terephthalate; PMMA, polymethyl methacrylate; PP, polypropylene; PS, polystyrene; PTFE, polytetrafluoroethylene; PU, polyurethane; PVC, polyvinyl chloride; RDF, refused derived fuel; SD, standard deviation; SEM, scanning electron microscopy; SRB, sulphate-reducing bacteria; TDPA, totally degradable plastic additives; TGA, thermogravimetric analyser; TOC, total organic carbon; VOCs, volatile organic compounds; WtE, waste to energy; WtM, waste to material; XRF, X-ray fluorescence 


\section{Introduction}

Over the last two decades, the amount of waste being managed by landfill disposal each year has decreased across Europe and the UK. According to the Eurostat (2016) waste estimation, $473 \mathrm{~kg}$ per capita of MSW was generated in 1995 in EU-27, of which 64 wt \% were disposed in landfill and 11 wt \% were recycled. In 2015, the EU-27 reported $477 \mathrm{~kg}$ of MSW per capita of which 28 wt $\%$ were recycled, 26 wt $\%$ incinerated (including energy recovery), 25 wt $\%$ landfilled, and $16 \mathrm{wt} \%$ were processed by composting and digestion (Eurostat, 2016). New legislation, such as Council Directive 1999/31/EC (European Parliament. Council of the European Union 1999) and Waste Framework Directive 2008/98/EC (European Parliament. Council of the European Union, 2008), has driven the changes in the management of landfill, encouraged sustainable waste management and resulted in the closure of many landfills (Hogland et al., 2011). The waste management hierarchy included in Framework Directive 2008/98/EC has become part of the European waste management, defining different aspects of this topic such as waste, recycling, recovery, secondary raw materials and by-products (European Commission, 2016).

Recently, Europe has moved towards the 'new' concept of a Circular Economy, aiming to recycle $65 \mathrm{wt} \%$ of MSW and reduce the amount of MSW disposed in landfill by $10 \mathrm{wt} \%$ before 2030 (European Parliament. Council of the European Union, 2015). However, there are between 125,000 and 500,000 landfills (EURELCO, 2017) in Europe, many of which are now closed; waste in landfills represents an important legacy that needs to be addressed. It is estimated that over 5.25 billion tonnes of waste were deposited in landfills between 1995 and 2015 across the EU-27 countries (Eurostat, 2016). The first landfill mining (LFM) project was carried out in Israel in 1953 (Savage et al., 1993), but only until the late 1980s, interest began to increase, especially in USA and Europe (Hogland et al., 2004). The concept of enhanced landfill mining (ELFM), which started to develop in 2008 (Jones et al., 2013), 
focuses on maximising the valorisation of waste found in landfills and dump-sites as material (WtM) and energy (WtE) (Jones et al., 2012). Landfills can be considered as temporary storage for waste while the technologies for their valorisation are improved and achieve largescale deployment (Bosmans et al., 2013). Landfills operating between the 1950s to the mid1990s have been identified as the most suitable for ELFM, because they were not affected by the directives that lead to a minimization and pre-treatment of waste disposed in landfills and have higher content of valuable and combustible materials (Hogland et al., 2011; Van Passel et al. 2013).

A key challenge exists in the recovery of value from materials excavated from landfills, which has been partially addressed in previous academic publications, however this review specifically focuses on plastics. Here there is an opportunity to explore alternative methods of recovering value from plastics as conventional recycling/recovery methods will not be viable. Similarly, recovery of energy from waste and advanced conversion processes require further research and development due to the pollution and the unknown effects of landfill contamination on the chemical transformation pathways.

A variety of the landfilled materials can theoretically be recycled or used for energy recovery, which can contribute to the security of energy supply and substitute raw materials (Greedy, 2016). For example, recovery of secondary raw materials available within landfills such as valuable metals (Gutiérrez-Gutiérrez et al., 2015) can mitigate the increasing concern about the availability and security of critical raw materials (European Commission, 2017). Opportunities also exist in the recovery of plastics, which represent between 5-25 wt $\%$ of the total waste deposited; the proportion increases in landfills during time due to the degradation of organic matter and its consequent weight loss (García et al., 2016; Sel et al., 2016; Münnich et al., 2015; Quaghebeur et al, 2013; Jones et al., 2013; Van Passel et al., 2013; Van Vossen and Prent, 2011). 
The annual worldwide plastic production has increased from 1.5 Mt in the $1950 \mathrm{~s}$ to $322 \mathrm{Mt}$ in 2015 (PlasticsEurope, 2016). In 201459 Mt and 311 Mt of plastics were generated in Europe and in the world respectively (PlasticsEurope, 2016). In the same year, of 25.8 Mt of plastic waste produced, $29.7 \mathrm{wt} \%$ were recycled, $39.5 \mathrm{wt} \%$ used for energy recovery and $30 \mathrm{wt} \%$ were landfilled (PlasticsEurope, 2016). Over the years, the inadequate plastic waste management has led to the accumulation of plastics in the environment, causing pollution and consequent health risks (Singh and Ruj, 2016; Thompson et al., 2009). The conjunction of increasing energy demand and scarce resources such as fossil fuel has resulted in a need for sustainable secondary fuels and chemical resources (Sharma et al., 2014; Singh and Ruj, 2016). Plastics from landfills can potentially be reprocessed to other plastic products, used as part of a waste-derived fuel for energy or used as a feedstock to produce valuable base petrochemicals (Al-Salem et al., 2009; Mastellone, 1999). Because $90 \%$ of the plastic are produced from petroleum, pyrolysis of plastic waste is considered a feasible process to recover chemical building blocks and a valuable alternative to the ordinary plastics disposal routes, such as landfill (Al-Salem et al., 2009; Al-Salem and Lettieri, 2010).

Critical reviews and studies on technical and economic aspects of LFM and ELFM has been previously published (Krook et al., 2012; Jones et al., 2013; Bosmans et al., 2013; Van Passel et al.; 2013). However, these do not focus on the excavated plastic waste fraction and therefore do not consider its chemical characteristics. This paper reviews the research focusing on excavated plastics and the physico-chemical properties of this fraction along with the gaps in scientific knowledge that need to be filled to consolidate and enable development of upcycling technologies. The aim of the work is to critically review the likely impacts of landfill chemistry on the degradation and/or contamination of plastic waste and its properties, and assess the viability of using excavated plastic waste as feedstock for upcycling to valuable chemicals or liquid fuels via thermochemical conversion. 


\section{Plastic components of landfill waste and factors affecting their degradation}

\subsection{Plastic components of landfill waste}

Plastics can be thermoplastic, which are capable of melting and flowing at a certain temperature without undergoing chemical changes, and thermoset such as bakelite, which are characterised by irreversible cross-linked polymer chains formed at high-temperature treatments (Jasso-Gastinel et al., 2017). The molecular structure is characterised either by a random arrangement of polymer chains forming an amorphous structure such as PS and PVC, or by an alternation of random and regular orders forming semi-crystalline structure such as PE and PP (Gilbert, 2017).

Thermoplastics have secondary bonding between molecules while thermosets cross-linking often have primary covalent bonds and occasionally hydrogen bonds (Lampman, 2003). Chemical reactivity and thermal stability are related to the primary bonds while the solubility of the polymers is associated with the secondary bonds (Brydson, 1999).

Thermoplastics include polyethylene (PE), which can be sub-divided into low-density (LDPE) and high-density polyethylene (HDPE), polyethylene terephthalate (PET), polypropylene (PP), polystyrene (PS), and polyvinyl chloride (PVC). Thermoplastics represent approximately $80 \mathrm{wt} \%$ of the consumed plastics and constitute most of the plastic fraction of municipal plastic waste (Dewil et al., 2006; Andrady and Neal, 2009; Lettieri and Al-Salem, 2011).

\subsection{Factors affecting plastic waste degradation}

Their chemical composition and structure influence their degradation behaviour (Brydson, 1999). Thus, polymers with heteroatoms such as PET, are more susceptible to degradation 
than polymers with pure carbon backbones (Zheng et al., 2005; Müller et al., 2001). The water permeability of plastics is directly proportional to their polarity; hence nonpolar polymers are less affected by water permeability (McKeen, 2014).

Most common plastics can be classified from the most polar to the less polar as follows: PET > PU > PC > PS > PE > PP (McKeen, 2014). Polymers with unsaturated double bonds are more prone to degradation than polymers with saturated bonds (Gewert et al., 2015). However, the presence of impurities, such as traces of catalyst residues, additives, or metals from processing equipment can accelerate/initiate degradation of polymers with saturated bonds, i.e. PE, PP and PVC (Gijsman et al., 1999, Grassie and Scott, 1988, Scott, 2002, Vasile, 2005, cited in Gewert et al., 2015).

The degree of unsaturation (DoU) gives information on the unsaturated (double, triple and rings) bonds present in the monomer. The fluidity of the polymer is directly proportional to the degree of unsaturation, increasing the saturation level the fluidity decreases. DoU of a polymer can be calculated from its repeating unit (Equation 1), which does not consider the $\mathrm{O}$ and $\mathrm{S}$ due to their neutrality in saturation (McKeen, 2014).

Equation 1. Formula of polymer degree of unsaturation.

$$
D o U=\frac{2 C+2+N-X-H}{2}
$$

where $\mathrm{C}$, number of carbon; $\mathrm{N}$, number of nitrogen; $\mathrm{X}$, number of halogen $(\mathrm{F}, \mathrm{Cl}, \mathrm{Br}, \mathrm{I}) ; \mathrm{H}$, number of hydrogen.

Degradation of plastics in the environment can occurs either by photodegradation, autooxidative degradation, thermooxidative degradation, thermal degradation and biodegradation (Andrady, 2001). The degradation process is normally initiated by UV-light and heat 
followed by auto-oxidation of the polymers and scissions into smaller polymer fragments which can be degraded by microorganisms (Andrady, 2011).

Degradation of plastic waste in landfills covers a period over 20 years and it is mainly related to thermooxidative degradation and anaerobic condition (Webb et al., 2013). The most common cause of degradation of polymers without heteroatoms, such as PP, PE and PS, in an aerobic environment, is the photodegradation followed by oxidation (Gijsman et al., 1999). Fig. 1 shows the mechanism for a general polymer auto-oxidation process. Free radicals are initially formed from photo and thermal degradation. They react in the presence of oxygen to form peroxy radicals, which further react with organic material leading to hydroperoxides formation (ROOH) (Gijsman, 2008). New radicals are generated from the hydroperoxides, sustaining the process. Transition metals such as $\mathrm{Fe}, \mathrm{Cu}$, Ti and $\mathrm{Cr}$ can accelerate the degradation process (Gijsman, 2008). Transition metals such as Fe, Co, and Mn, can catalyse the formation of free radicals from hydroperoxides (Ammala et al., 2011). Photodegradation is more affected by iron, while thermal degradation is catalysed by cobalt and manganese (Ammala et al., 2011).

\section{>>>> Insert Figure $1<<<<<<~$}

Thermooxidative degradation, which occurs at moderate temperature $\left(\sim 70{ }^{\circ} \mathrm{C}\right)$, is one of the main oxidative degradation steps (Andrady, 2011; Gijsman, 2008).

Several studies reported anaerobic biodegradation of plastics in landfills into water and methane (Gu et al., 2000 cited in Shah et al., 2008). The polymers are broken down into shorter chains by microorganism enzymes, until they reach a small size $\left(M_{n} \sim 500 \mathrm{~g} / \mathrm{mol}\right)$ and are able to penetrate the bacterial membranes (Andrady, 2011; Shah et al., 2008). Muenmee et al. (2016) also found that semi-aerobic condition in landfills enhanced the plastics biodegradation and decreased the methane emission. In aerobic conditions, biodegradation 
produces $\mathrm{CO}_{2}$ and $\mathrm{H}_{2} \mathrm{O}$ (Shah et al., 2008). Adamcová and Vaverková (2014) studied the degradation of HDPE with totally degradable plastic additives (TDPA) and $100 \%$ degradable PE samples placed in Štěpánovice landfill for a period of 12 months. Neither decomposition nor degradation was found in the samples, and only a change in colour was reported (Adamcová and Vaverková, 2014). This observation is likely to be because degradation of plastics is a long process and requires years to occur. Table 1 shows some degradation characteristics of most common plastics types.

>>>> Insert Table $1<<<<<<~$

Plastic degradation affects the material physical properties leading to visible changes, such as discoloration and brittleness, and chemical changes, such as bond scissions and new functional groups formation (Pospisil and Nespurek, 1997; Shah et al., 2008). Microorganisms tend to attack the amorphous polymer structure while the crystalline component, characterised by slower degradation, is separated from the material structure (Shah et al., 2008). Moreover, the degradation of plastics releases pollutants into the air and leachate, such as benzene, toluene, xylenes, ethylbenzenes, trimethyl benzenes, bisphenol A (BPA) and nonylphenols (NP) (Teuten et al., 2009; Tsuchida et al., 2011; Urase et al., 2008; Webb et al., 2013; Xu et al., 2011).

Further to this, several factors can influence plastic degradation in landfills such as presence of oxygen, leachate, corrosive chemicals, relatively elevated temperature, and acidic $\mathrm{pH}$. Hydrogen sulphide $\left(\mathrm{H}_{2} \mathrm{~S}\right)$ is one of the chemicals that can cause corrosion of plastics (Table 2). $\mathrm{H}_{2} \mathrm{~S}$ formation occurs in landfills when sulphate-reducing bacteria (SRB) convert sulphate $\left(\mathrm{SO}_{4}^{2-}\right)$ to sulphite $\left(\mathrm{SO}_{3}^{2-}\right)$, and this into sulphide $\left(\mathrm{S}^{2-}\right)$ and $\mathrm{H}_{2} \mathrm{~S}$ at low $\mathrm{pH}$ (Ko et al, 2015; Tsuchida et al., 2011). Different types of waste have an opposite effect on $\mathrm{H}_{2} \mathrm{~S}$ production. Co- 
disposed landfill waste can influence $\mathrm{H}_{2} \mathrm{~S}$ production changing the $\mathrm{pH}$ in the landfill; for example concrete increases the $\mathrm{pH}$ whereas wood waste decreases the $\mathrm{pH}$ under the optimum SRB pH range (Yang et al., 2006). New waste has greater influence on the increase in the level of $\mathrm{H}_{2} \mathrm{~S}$ than aged waste due to the decrease of sulphur compounds with time (Ko et al, 2015). Tsuchida et al. (2011) remarked the use of some organic plastic additives such as phenols and organic phosphates as electron donors by $\mathrm{SRB}$ for $\mathrm{H}_{2} \mathrm{~S}$ production in inert waste landfills. In addition, SRB uses gypsum drywall, organic waste and sludge of wastewater treatment plants as a sulphur source in landfills in anaerobic condition (Ko et al, 2015). The activity of SRB is also affected by the presence of nitrate and ferric compounds which increase the propagation of nitrate and iron reducing bacteria respectively (Eckford and Fedorak, 2002; Lovley, 1991).

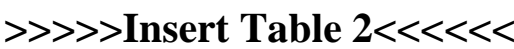

Plastic contains a variety of additives which during degradation can leach in the environment increasing the risk of pollution (Beißmann et al., 2013; Prudent et al, 1996; Quaghebeur et al., 2013; Teuten et al., 2009). Parameters such as the polymer pore size, the size and type of additive and temperature, influence the release mechanisms of additives from polymers in landfills (Teuten et al., 2009). Furthermore, leachates can exhibit different characteristics, such as $\mathrm{pH}$ and ionic strength, which result in different additive extraction potentials (Xu et al., 2011; Teuten et al., 2009). Additives are typically used to enhance the processing and the properties of plastic. Generally, additives with short alkyl chains tend to be more readily released in the leachate than those with longer alkyl chains (Teuten et al., 2009).

Phthalates (alkyl/aryl esters of 1, 2-benze-nedicarboxylic acid) are commonly used as plasticisers in PVC (Hahladakis et al. 2018). It has been reported that plasticisers with high solubility such as dimethyl phthalate (DMP) are released in landfills in greater amounts than hydrophobic plasticisers such as diethyl-hexyl phthalate (DEHP) (Teuten et al., 2009). Migration of plasticiser decreases when the polymer reaches its glass transition state 
(Ejlertsson et al. 2003). Alkylphenols are additives with plasticising and stabilising properties (Hahladakis et al. 2018; Teuten et al., 2009). Organotin compounds are highly used in rigid PVC as stabilisers and can be toxic for humans (Folarin and Sadiku, 2011). The release of phthalate esters and organotin compounds occurs in the neutral leachate of the methanogenic phase (Bauer and Herrmann 1998; Björn et al., 2007). BPA, which is used in building blocks of polycarbonate plastics, PVC and printer ink, has been reported to be released from the polymer in the acidogenic phase (Asakura et al., 2004). Different plastic types such as polycarbonates and epoxy resins can release BPA in the leachates, and for this reason larger quantity of plastic waste can lead to a major dispersion of this pollutant in the environment (Xu et al., 2011; Teuten et al., 2009).

Leachate characteristics are variable (Table 3) along with its potential to degrade plastics and their additives (Teuten et al., 2009). Thus, the leachate from anaerobic landfills tends to be more acidic than that from semi-aerated landfills, due to the high amount of putrescible organic during the anaerobic degradation of MSW, and a higher concentration of BOD, COD and ammonia (Cossu et al., 2003). During the acetogenic phase, the leachate presents low $\mathrm{pH}$ level and high ionic strength which inhibit the release of plasticisers (Bauer and Herrmann, 1998). Some example of leachate chemicals which can affect plastics are given in Table 4. On the other hand, plastics have also a fundamental role as a sorbent organic matter for hydrophobic organic contaminants (HOCs) (Saquing et al., 2010). For this reason, plastics from landfill are likely to carry HOCs for instance toluene. Glassy or hard plastics which have high glass-transition temperature such as $\mathrm{PVC}\left(\mathrm{T}_{\mathrm{g}} 87^{\circ} \mathrm{C}\right)$, are characterised by slower desorption of HOCs than rubbery or soft polymers such as PE $\left(\mathrm{T}_{\mathrm{g}}-78^{\circ} \mathrm{C}\right)$ (Saquing et al., 2010; ASM International, 2003; Yang et al., 2016). 


\section{>>>> Insert Table $4<<<<<<~$}

\section{Landfill mining projects for recovering plastic waste}

Although $\sim 700$ landfill mining projects have been carried out, project setup and parameters included are not always fully detailed making difficult to compare the results of different studies (Krook et al., 2012).

Tielemans and Laevers (2010) investigated the "Closing the circle" project for the landfill site of Group Machiels in Belgium, studying the material distribution and energy valorization. The samples comprise of MSW waste and IW waste excavated from REMO landfill. The thermal valorisation was based on the process of RDF from the excavated waste through a Gasplasma ${ }^{\mathrm{TM}}$ system. The excavated waste was classified in three fractions based on particle size, fine fraction $<4 \mathrm{~mm}$, fraction between $4-10 \mathrm{~mm}$ and fraction $>10 \mathrm{~mm}$; the fraction $<10 \mathrm{~mm}$ represented the highest percentage, between 44-56 wt \% for MSW and 6480 wt $\%$ for IW (Tielemans and Laevers, 2010). Plastics suitable for material valorisation were identified in the fraction $>4 \mathrm{~mm}$ (Tielemans and Laevers, 2010). Gasplasma ${ }^{\mathrm{TM}}$ was identified as an appropriate technology for landfill waste to energy valorisation using RDF as feedstock (Tielemans and Laevers, 2010).

Quaghebeur et al. (2013) characterised the excavated waste for REMO landfill in Belgium, which maximum storage time was between 9-29 years. Chemical characteristics of the excavated plastic following years of storage are summarised in Table 5. The waste was manually sorted and not washed, for this reason plastic analyses were influenced by impurities such as soil particles (Quaghebeur et al., 2013). Plastic from IW presented a higher amount of metals than plastic from MSW (Table 5) (Quaghebeur et al., 2013). TOC of plastic from IW and MSW was similar, and plastic degradation was found to not have a significant effect on calorific value (Quaghebeur et al., 2013). The authors concluded that the 
thermochemical processing of recovered plastic to produce energy is a feasible alternative to recycling because they present a good level of calorific value (18-28 MJ/kg), and cannot produce high-quality recycled material due to high level of contamination (Quaghebeur et al., 2013).

Zhou et al. (2014) analysed excavated plastics from Yingchun MSW landfill in China, which had a maximum storage of 24 years (Table 5, Table 6). The amount of plastics was larger in the layers between 1997 and 2004 than that from the period from 1989 to 1996 . The total plastic samples were divided in white 'PE bag' (11.3 wt \%), 'coloured PE bag' (29.8 wt \%), 'other plastic bag' (28.0 wt \%) and 'other mixed plastics' (30.9 wt \%) (Zhou et al., 2014). The presence of soil and sand impurities in plastics were high $(71.0 \pm 6.3 \mathrm{wt} \%)$, especially in the older plastics stored for longer periods (Zhou et al., 2014). The major pressure present in the deepest layers could be a reason for resistance of impurities, embedded in plastics, even after washing them (Zhou et al., 2014). The calorific value is not affected by the years of storage (Quaghebeur et al., 2013; Zhou et al., 2014).

According to Zhou et al. (2014) and Quaghebeur et al. (2013) alteration of ultimate analysis results, such as higher level of oxygen, silicon and aluminium content in excavated plastic waste compared to fresh plastic waste (this term refers to plastic waste that has not been in landfill), is probably related to the presence of impurities, such as soil and sand particles, which major constituents are $\mathrm{SiO}_{2}, \mathrm{Al}_{2} \mathrm{O}_{3}$, oxynitride etc.

The recycling potential of excavated plastic waste from the Nonthaburi dumpsite in Thailand has been analysed in two different studies (Prechthai et al., 2008; Chiemchaisri et al., 2010). In Prechthai et al. (2008) study the excavated MSW (Table 6) samples were stored 3-5 years and were divided in particle size ranges $<25 \mathrm{~mm}$, between $25-50 \mathrm{~mm}$ and $>50 \mathrm{~mm}$. $90 \mathrm{wt} \%$ of the plastics were recovered from the coarse fraction $(>50 \mathrm{~mm})$ and $10 \mathrm{wt} \%$ from the 
medium particles fraction (25-50 mm) (Prechthai et al., 2008). In Chiemchaisri et al. (2010) plastic waste was taken as well from Nonthaburi dumpsite in Thailand and the maximum storage time was 10 years (Table 6). They divided the excavated plastics into 'carry bags', 'other bags' and 'other plastic'. Excavated plastic was found in both studies to have the potential to be recycled as RDF after further processing (Prechthai et al., 2008).

Wolfsberger et al. (2015) chemically analysed the plastic fraction found in two different landfills in Austria. The maximum storage age was 20 and 30 for landfill site 1 (LF1) and landfill site 2 (LF2) respectively. The plastic fraction from LF2 showed a higher level of lead, cadmium, chromium, cobalt and mercury. The reason was attributed to the fact that the waste disposed in LF2 was pre-treated in the MBT before disposal and was not related to a longer storage time.

Bhatnagar et al. (2017) assessed the value of waste material excavated from the municipal landfill of Kudjape in Estonia, between 2012 and 2013. The analysed waste was stored 4-8 years. The plastic waste fraction was comprised of different types of plastics and textile because it was not possible to distinguish the synthetic textile from the natural textile. The waste PE represented the highest profit between all the plastic waste. The authors stated that soft plastic (e.g. PE), which represented $20 \mathrm{wt} \%$ of the excavated materials, has potential for an income with a hypothetical market value of $35 € / t$ (Ventosa et al., 2014). Furthermore, SRF was considered as the most marketable materials after applying a pre-treatment to reduce the moisture content.

>>>> Insert Table $5<<<<<<$

>>>> Insert Table $6<<<<<<$ 


\section{Applicability and limitation of the current recycling technologies for energy recovery from excavated plastics}

Fresh plastic waste is recovered in different ways, which can be summarised as reuse (primary), mechanical recycling (secondary), chemical or feedstock recycling (tertiary) and energy recovery (quaternary) (Al-Salem et al., 2009; Datta and Kopczyńska, 2016). Primary recycling involves the re-extrusion of semi-clean plastic scrap to produce similar material (Al-Salem et al., 2009). In the secondary or mechanical recycling, the plastic waste preferably characterised by single-polymer is processed by mechanical means to produce new products, for example the production of polyester fibers from PET bottles (Al-Salem et al., 2009). Tertiary recycling, or chemical and thermochemical recycling, involves the production of feedstock from plastic waste to be used as fuel or for synthesis of petrochemicals and plastics but for the moment there are no large-scale industrial applications (Al-Salem et al., 2009; Mastellone, 1999). Quaternary recycling, or energy recovery, involves the production of heat, steam and electricity from thermochemical processes, such as incineration (European Parliament. Council of the European Union, 2008; Korai et al., 2016).

Both fresh plastic waste and excavated plastic waste need to meet certain requirements concerning the presence of chemical elements to be applicable for recycling process (Johansson et al., 2017). REACH (European Parliament, 2009) established a series of restrictions on dangerous substances. For example, $\mathrm{Cd}$ limit in plastic products is $0.01 \mathrm{wt} \%$, phthalates, used in plastics additives such as benzyl butyl phthalate, dibutyl phthalate, diisononyl phthalate and diisodecyl phthalate, must not exceed $0.1 \mathrm{wt} \%$ if plastic is going to be used in toys and childcare articles (European Parliament, 2009). As it is summarised in

Table 5, excavated plastic waste may content $\mathrm{Cd}$ and other heavy metals in concentrations that exceed the $0.01 \mathrm{wt} \%$ limit. This high level of impurities makes the reuse of excavated plastics more challenging than the reuse of fresh plastic waste, and creates uncertainties on 
the profitability of the products which should conformed to industry standards (Bosmans et al., 2014; Breyer et al., 2017; Zhou et al., 2014).

\subsection{Sorting}

Sorting of plastics is an important step to enhance plastic recovery and recycling, and changes depending on the nature of feedstock, recycling method applied and product required. Common sorting techniques of plastic waste are summarised in Table 7.

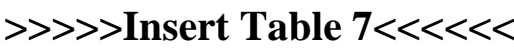

Excavated waste can be separated into different sizes and streams using a series of processes such as screening, air separation, metal separation and wet separation (Vrancken et al., 2017). The different types of plastic waste can be further divided with sorting methods such as hydrophobicity method and optical technologies (Vrancken et al., 2017). The impurities present in the excavated plastic waste can modify their properties and thus interfere with the sorting process, especially with technique sensor based, such as NIR (near infrared). In addition, separation based on density differences will be difficult for excavated plastics as the presence of impurities can change their density (Zhou et al., 2014). Other techniques can be employed in the sorting excavated plastics, such as triboelectric separation, speed accelerator, X-ray fluorescent (XRF) spectroscopy but further research is needed to assess their applicability on excavated plastic waste (Al-Salem et al., 2009).

\subsection{Mechanical recycling}

Mechanical recycling of plastic waste involves a series of processes including pretreatment: cutting/shredding, contaminant separation, sorting, milling, washing and drying, 
agglutination, extrusion and pelletization, and quenching (Al-Salem et al., 2009; Aznar et al, 2006; SubsTech, 2013). Prior to secondary recycling, the plastics need to be sorted and washed (Al-Salem et al., 2009).

As in the case of fresh plastic waste, mechanically-treated excavated plastic can be used as construction materials. For example, different types of plastics such as PET, PC, PVC and PE could be mixed with concrete, improving its ductility and reducing the risk of concrete cracking (Saikia and de Brito, 2012; Sharma and Bansal, 2016). Nevertheless, they need to meet the limit criteria for leaching and exposure (Johansson et al., 2017), and the typical pollutants present in plastic waste, such as lead, cadmium, chromium and BPA, represent a leaching risk (Saikia and de Brito, 2012). Mechanical recycling of excavated plastic waste faces three main problems which are the uncertainties of chemical and physical condition of excavated plastic waste, regulatory framework and marketability. In fact, the variations on factors such as age and the environmental condition during storage do not allow to assume that sufficient cleaning of the treated waste can be always obtained. Furthermore, there are not univocal regulations, but they change in different countries. Moreover, for the moment there are no incentives to buy excavated material due to uncertainties in material quality and high cost derivate also from the treatment process which is needed to eliminate the impurities from the products.

\subsection{Energy recovery via incineration}

Plastic has a high calorific value that makes it feasible to be used as an energy source through incineration (Al-Salem et al., 2009). Nevertheless, incineration of synthetic polymers such as PVC, PET, PS and PE, leads to the production of air pollutants such as $\mathrm{CO}_{2}, \mathrm{NO}_{\mathrm{x}}, \mathrm{SO}_{\mathrm{x}}$, volatile organic compounds (VOCs), particulate-bound heavy metals, polycyclic aromatic hydrocarbons (PAHs), polychlorinated dibenzofurans (PCDFs) and dioxins (Al-Salem et al., 
2009). Therefore, high-performance cleaning units are required in-situ or downstream of the furnace to clean the flue gases at the required levels. Various technologies are applied, such as ammonia addition to the combustion chamber, flue gas cooling, acid neutralisation, activated carbon addition and filtration (Al-Salem et al., 2009; Yassin et al., 2005).

Plastics excavated from landfill, along with other combustibles, will contain impurities (Zhou et al., 2014) and elevated levels of heavy metals (Rotheut and Quicker, 2017) (Table 5 and Table 6) due to contact with soil-like fines and leachate exposure respectively. Therefore, the use of excavated landfill materials as RDF requires consideration of the increased emissions and utilisation of pre-treatment. Although Rotheut and Quicker (2017) concluded that conventional flue gas systems can cope with the increased emissions, technical performance of the existing cleaning strategies needs to be properly addressed. Consideration on the management of air pollution control residues (APCr) is also needed. Thus, the extra cost for the already expensive management of these hazardous residues due to the use of RDF from landfill and the impact on the gate fees associated with such RDF must be assessed.

\subsection{Chemical and thermochemical recycling}

Tertiary recycling covers a series of chemical and thermochemical technologies which yield products that can be used as fuels or feedstock for synthesis of chemicals and new plastics (see Fig. 2). During chemical recycling, the polymer chains are broken with the aid of decomposition agents such as diols, alcohols, and amines, at a relatively low temperature around $200{ }^{\circ} \mathrm{C}$ (Zia et al., 2007). On the other hand, the thermochemical recycling uses higher temperatures $\left(300-1000{ }^{\circ} \mathrm{C}\right.$ ) and reacting atmospheres such as $\mathrm{H}_{2}, \mathrm{H}_{2} \mathrm{O}$ or stoichiometric content of $\mathrm{O}_{2}$ to produce monomers, fuels and industrial chemical precursors (Datta and Kopczyńska, 2016). 
Zhou et al. (2014) concluded that incineration and RDF production was the most convenient treatment for excavated plastics based on input requirements, which in the case of pyrolysis were identified as particle size between $1-20 \mathrm{~mm}$, moisture $<0.5 \mathrm{wt} \%$ and ash $<2 \mathrm{wt} \%$. However, pyrolysis produces syngas and usable solid residue, with less $\mathrm{NO}_{\mathrm{x}}$ and $\mathrm{SO}_{\mathrm{x}}$ emissions than incineration (Younan et al., 2016). In addition, the capital costs for pyrolysis gas treatment is less expensive than the incineration gas treatment because it has a smaller volume (Bosmans et al., 2013). Datta and Kopczyńska (2016) recognised pyrolysis as an adequate technology to recover high yield of monomers from fresh plastic waste especially PS, PMMA and PTFE, when comparing tertiary recycling processes such as pyrolysis, catalytic cracking, hydrogenation and gasification.

Bosmans et al. (2014) analysed the pyrolysis kinetics for excavated waste to identify the optimum parameters to maximise the product yield. They used a mixture of RDF obtained from excavated MSW and IW, with 29 and 24 years of maximum storage respectively. The results showed that the 'less stable plastics' $(\mathrm{E}=99 \mathrm{~kJ} / \mathrm{mol})$ had lower activation energy than fresh waste, which may be related to changes of the excavated waste properties compared to fresh waste in composition, and the catalytic effect of impurities such as metals (Bosmans et al., 2014). Breyer et al. (2017) used excavated plastics from Mont-Saint-Guilbert landfill in Belgium in co-pyrolysis with lubrication oils. Most plastics were categorised as LDPE (85 wt $\%$ ) while the rest (15 wt \%) included PE, PP, PS and PET (Breyer et al., 2017). The plastics presented a variety of contaminants such as wood, textile, fines and metals. The degradation temperature increased with the mixture of plastics and oil, by maximum $20{ }^{\circ} \mathrm{C}$, compared to the decomposition process of individual material (Breyer et al., 2017). The authors concluded 
that the co-pyrolysis of excavated plastic with oil was feasible even from an energy point of view; indeed, the combustion of the produced pyrolysis liquid yielded greater energy than that consumed during its production process (Breyer et al., 2017).

Santaweesuk and Janyalertadun (2017) studied the production of fuel oil by slow thermal pyrolysis of excavated plastic waste (PP, LDPE, HDPE and mixed plastics) from the Warinchamrap municipal landfill, Thailand. The parameters used were temperature between 350 and $450{ }^{\circ} \mathrm{C}$, atmospheric pressure, and retention time 4-6 hours. The gas was condensed at $25-30{ }^{\circ} \mathrm{C}$. The yields of liquid fuel were $80 \mathrm{wt} \%, 73 \mathrm{wt} \%, 70 \mathrm{wt} \%$ and $46 \mathrm{wt} \%$ for PP, LDPE, HDPE and mixed plastics respectively. The pyrolysis liquid fuel was then distilled, and it was found to be a mixture of heavy naphtha $\left(\mathrm{C}_{7}-\mathrm{C}_{10}\right)$, gasoline $\left(\mathrm{C}_{8}-\mathrm{C}_{10}\right)$ and light gas oil $\left(\mathrm{C}_{10}-\mathrm{C}_{20}\right)$. Higher operating temperature was found to increase the liquid and gas products. The authors concluded that quantity and quality of the produced pyrolysis liquid fuel is influenced by the plastics type.

The pyrolysis of plastic waste has been largely studied (Anuar Sharuddin et al., 2016) compared with the pyrolysis of excavated plastic waste, which can benefit from the findings of the former. The properties of pyrolysis oil from plastic waste and excavated waste are similar to petroleum diesel oil (Miandad et al., 2016; Santaweesuk and Janyalertadun, 2017). In most of the studies on pyrolysis of plastic waste the heating rate was between 10 and 25 ${ }^{\circ} \mathrm{C} / \mathrm{min}$ (Anuar Sharuddin et al., 2016). Various sweep gases have been used in pyrolysis of plastics; nitrogen is the most common one due to its relatively low reactivity, but also helium, argon, ethylene, propylene and hydrogen (Anuar Sharuddin et al., 2016). Typical reactors used for pyrolysis of plastics are fluidized bed reactors, batch reactors and screw kiln reactors (Kumar et al., 2011). Each type of reactor allows a different heating rate which affects the final product distribution. Thus, fluidized bed reactors allow a rapid heating and more uniform heat distribution within the unit (Kunwar et al., 2016), and are preferred for 
enhancing the production of the liquid fraction via fast pyrolysis. However, fluidization reactors require higher maintenance and capital cost compared to fixed bed reactors (Chen et al., 2015). Table 8 summarises the pyrolysis types according to the heating rate, final temperature and residence time employed. As explained above, pyrolysis product distribution depends on the temperature used during processing. In the case of plastics, temperatures $>500$ ${ }^{\circ} \mathrm{C}$ lead to more gas formation, while liquid yield is major at a lower temperature around 450 ${ }^{\circ} \mathrm{C}$ (Anuar Sharuddin et al., 2016; Miandad et al., 2017). Singh and Ruj (2016) stated that at higher heating rate the degradation is partially prevented due to shorter residence time of the volatile products at high temperature. Residence time is therefore particularly important, mainly when the process runs at temperatures $<450{ }^{\circ} \mathrm{C}$; at higher temperatures, its effect is less evident (Anuar Sharuddin et al., 2016). General problems related to the properties of plastic waste, such as the sticky behaviour of fused plastics, may compromise the reactor performance during pyrolysis (Lopez et al., 2017). Fast pyrolysis is normally the most appropriate operating mode to avoid this issue due to its high heat transfer rate (Lopez et al., 2017).

>>>> Insert Table $8<<<<<<~$

Pyrolysis of fresh plastic waste has been largely studied especially using thermogravimetric analyser (TGA) and laboratory scale reactors (Wong et al., 2016). Kunwar et al. (2016) studied the kinetics of pyrolysis of plastics using TGA. The activation energy was found to necessarily change according to the different number and type of bonds; for example, $\mathrm{C}-\mathrm{C}$ has lower dissociation energy than $\mathrm{C}-\mathrm{H}$ and $\mathrm{C}=\mathrm{C}$, i.e. 347,414 and $611 \mathrm{~kJ} / \mathrm{mole}$ respectively (Brydson, 1999; Kunwar et al., 2016). Sørum et al. (2001) used differential thermogravimetric (DTG) curves to identify the temperatures of the maximum degree of weight loss for PS, PP 
and LDPE, being 413,456 and $472{ }^{\circ} \mathrm{C}$ respectively. Discrepancy of results obtained on the activation energy and degradation temperature values may be present in different studies due to the diverse methods of calculation and parameters used (Grammelis et al., 2009; Sørum et al., 2001).

Grammelis et al. (2009) examined the thermal stability of some thermoplastics, classifying them from the most stable, that decomposes at high temperature, to the less stable: PC $\left(\right.$ maximum rate $\left.510^{\circ} \mathrm{C}\right)>\operatorname{HDPE}\left(\right.$ maximum rate $\left.495^{\circ} \mathrm{C}\right)>\operatorname{LDPE}\left(\operatorname{maximum}\right.$ rate $\left.495^{\circ} \mathrm{C}\right)>$ $\mathrm{PP}\left(\right.$ maximum rate $\left.\sim 460{ }^{\circ} \mathrm{C}\right)>\mathrm{PA}\left(\right.$ maximum rate $\left.\sim 455^{\circ} \mathrm{C}\right)>\mathrm{PS}\left(\right.$ maximum rate $\left.\sim 450{ }^{\circ} \mathrm{C}\right)>$ PVC (maximum rate $320^{\circ} \mathrm{C}$ and $470{ }^{\circ} \mathrm{C}$ ). Furthermore, they identified the order of activation energy, i.e. the energy required to start the pyrolysis, as follow: $E_{\mathrm{HDPE}}(445.2 \mathrm{~kJ} / \mathrm{mol})>\mathrm{E}_{\mathrm{LDPE}}$ $(437.1 \mathrm{~kJ} / \mathrm{mol})>\mathrm{E}_{\mathrm{PS}}(414.9 \mathrm{~kJ} / \mathrm{mol})>\mathrm{E}_{\mathrm{PP}}(373.4 \mathrm{~kJ} / \mathrm{mol})>\mathrm{E}_{\mathrm{PC}}(340.7 \mathrm{~kJ} / \mathrm{mol})>\mathrm{E}_{\mathrm{PA}}(256.6$ $\mathrm{kJ} / \mathrm{mol}$ ) (Grammelis et al., 2009).

Singh and Ruj (2016) studied the pyrolysis kinetics of fresh plastic waste through TGA analysis and found that individual fresh plastic waste type and a simulated mixture of them degrade between 350 and $520{ }^{\circ} \mathrm{C}$ while the mixed fresh plastic waste starts to degrade at lower temperature $300-550^{\circ} \mathrm{C}$. No explanation for the decrease of degradation temperature was provided by the authors.

Caballero et al. (2016) studied the pyrolysis of plastic waste from landline and mobile phones, which comprises mostly of acrylonitrile-butadiene-styrene copolymer (ABS) and polycarbonate (PC). Aromatics were present in very high percentage (> $90 \%$ area of GC-MS spectra) in the liquid product, likely due to the catalytic effect of metals such as $\mathrm{Fe}, \mathrm{Co}, \mathrm{Ni}$, $\mathrm{Zn}$, etc. (Caballero et al., 2016). Most of the $\mathrm{Cl}$ and $\mathrm{Br}$ contained in the plastic waste was transferred to the pyrolysis gas as $\mathrm{HCl}$ and $\mathrm{HBr}$, which are corrosive and need to be removed before further gas utilisation (Caballero et al., 2016). The authors concluded that valuable 
chemicals can be extracted from the pyrolysis liquid of plastic waste such as styrene, toluene, ethyl-benzene and $\alpha$-methylstyrene (Caballero et al., 2016).

Catalytic pyrolysis is a possible modification to improve the quality of the product fractions in-situ and eliminate some pollutants. Some of the most common catalysts used in catalytic pyrolysis of plastic waste include NZ, ZSM-5, and HZSM-5 zeolites, fluid catalytic cracking (FCC) catalyst, $\mathrm{Al}_{2} \mathrm{O}_{3}$, and Red Mud (Miandad et al., 2016). Although catalytic pyrolysis can improve the product quality and reduce the required temperature, it has disadvantages such as high cost of catalysts and the limited possibility of catalysts reuse (Miandad et al., 2016).

Studies have shown that some plastics are better feedstocks for pyrolysis processes. Among the most common plastic waste, PS and PP have appropriate properties to be processed through pyrolysis, such as lower thermal degradation temperature compared to other plastics and good fuel properties (Miandad et al., 2016). On the other hand, PVC and PET are considered not suitable for pyrolysis. PVC yields a high level of chlorine into the pyrolysis products. PET gives rise to low liquid yields with a high level of benzoic acid in composition (Anuar Sharuddin et al., 2016; Miandad et al., 2016). PE tends to convert into wax instead of oil due to its long chain structures, although the utilisation of relatively higher temperature $\left(>500{ }^{\circ} \mathrm{C}\right.$ ) or catalysis can favour the wax cracking (Anuar Sharuddin et al., 2016; Miandad et al., 2016). In general, plastics with high volatile matter and low ash content are preferred to produce pyrolysis liquid (Abnisa and Wan Daud, 2014). The ash content in the excavated plastics has been found generally higher than that in fresh plastic waste, which may decrease the liquid yield (Zhou et al., 2013). Therefore, their use as pyrolysis feedstock requires comprehensive assessment. 


\section{Discussion on current trends and future developments}

While excavated plastic waste from landfills present a great opportunity of resource recovery, presence of impurities and contamination with trace heavy metals or corrosive compounds (see Table 5 and 6) hampered their use in conventional energy recovery processes. Further to this the heterogeneity of the plastic components found in landfill sites means that different environments characterised by the structure of the landfill or dump-site, the climate in the area and type of waste collected can influence the chemical and physical changes of the plastic waste in landfill. Mechanical recycling of excavated waste can be a valuable recycling route if the degree of degradation is low and the sorting step allows the separation of different plastic types. These aspects significantly affect the quality of the products therefore their marketability. Assessing a time limit to plastic storage in landfill can increase the feasibility of this route. It is also important to consider that the excavated plastic waste derives from plastics potentially produced decades ago and under less restrictive legislation on plastics production, which differs from the current requirements, such as the new restrictions introduced with REACH in 2009.

Incineration of excavated waste for energy recovery requires less pre-treatment and preparation than other process such as pyrolysis (Zhou et al., 2014). However, the emissions released, with a feedstock in the form of RDF, have been reported as being higher than the emissions from non-landfilled wastes. Whilst these elevated emissions are not expected to cause problems for current flue gas cleaning technologies, this requires further consideration due to the impacts on air pollution control residues. Important barriers for incineration of excavated plastic waste are the ash content, which has been found to be higher than $20 \%$ in different samples analysed, and the chlorine content, which should be less than $1.5 \%$ (Johansson et al., 2017). Effective sorting and separation of PVC can reduce the level of chlorine. 
Upcycling of excavated plastic waste through pyrolysis has been highlighted as an alternative option to conventional recycling or combustion. This process requires a series of pretreatments such as sorting, cleaning and drying. Understanding the heterogeneity of the excavated plastic waste and different changes in the chemical and physical characteristics of each type of excavated plastic due to the degree of degradation and variation in the levels of contamination is crucial to address their suitability as feedstock from thermochemical processing. The experiments on pyrolysis of excavated plastic have shown positive results but more studies are needed to identify the most suitable parameters in relation to the feedstock characteristics (Breyer et al., 2017; Santaweesuk and Janyalertadun, 2017).

Excavated plastic waste value can increase with an effective separation of different plastics resins with low contamination level. Although there are some technical barriers associated with the technologies used for the waste separation that need to be overcome to guarantee efficient sorting, pyrolysis of excavated plastic waste offers a promising alternative that contributes to (i) the reduction of fossil fuels for energy production, (ii) increased production of liquid fuels and (iii) support the economic feasibility of ELFM.

. Furthermore, there is a lack of specific legislation regarding the recycling of excavated plastic waste. However, the introduction of the ELFM concept into the EU Landfill Directive is the first step for regulating and promoting the use of secondary raw materials from landfill.

\section{Summary and conclusions}

Landfills potentially contain large quantities of resources, including plastics, which have the potential to be recycled and reintroduced into a circular economy. Pyrolysis of fresh plastic waste has been studied previously for the potential to convert the plastic waste into valuable building blocks which can be further used as fuels and chemical precursors. This paper has 
highlighted different aspects related to the use of excavated plastic waste and the possible process encountered during the storage in landfills which can be summarised as follow:

- Plastics represent 5-25 wt \% of the total waste in landfills. In 2014, 30 wt \% of the total plastic waste produced in Europe was disposed of in landfills;

- $80 \mathrm{wt} \%$ of the generated plastics is represented by thermoplastics which include a series of resins that have different chemical and physical characteristics. These differences lead to diverse degradation processes in the landfill;

- Plastic waste degradation in landfills may be caused by biological activity (e.g. microorganisms) and chemical decomposition via compounds such as $\mathrm{H}_{2} \mathrm{~S}$ (in gas and solubilised forms) and organic acids found in leachate;

- Excavated plastic waste generally presents higher level of ash, impurities and heavy metals than fresh plastic waste. For this reason, pyrolysis is a more viable alternative than conventional recycling and combustion;

- Separation of single-polymer plastics can improve the value of products from recycling of excavated plastic waste;

- Contamination level and degradation of excavated plastics need to be further studied to evaluate the production of valuable products through pyrolysis.

This review summarises key gaps in the scientific understanding of plastic degradation pathways in landfill environments. This impacts the viability of recycling plastics recovered from landfills using conventional methods, therefore further studies are required to enhance scientific evidence of the feasibility of managing excavated plastics through pyrolysis processes. 


\section{Acknowledgements}

The authors acknowledge the support received from the UK Engineering and Physical Sciences Research Council (EPSRC) through the Doctoral Training Partnership (DTP) (EP/N509450/1).

\section{References}

Abnisa, F., Wan Daud, W.M.A., 2014. A review on co-pyrolysis of biomass: An optional technique to obtain a high-grade pyrolysis oil. Energy Convers. Manage. 87, 71-85.

Adamcová, D., Vaverková, M., 2014. Degradation of biodegradable/degradable plastics in municipal solid-waste landfill. Pol. J. Environ. Stud. 23, 1071-1078.

Al-Salem, S.M., Lettieri, P., 2010. Kinetic study of high density polyethylene (HDPE) pyrolysis. Chem. Eng. Res. Des. 88 (12), 1599-1606.

Al-Salem, S.M., Lettieri, P., Baeyens, J., 2009. Recycling and recovery routes of plastic solid waste (PSW): A review. Waste Manage. 29, 2625-2643.

Ammala, A., Bateman, S., Dean, K., Petinakis, E., Sangwan, P., Wong, S., Yuan, Q., Yu, L., Patrick, C., Leong, K.H., 2011. An overview of degradable and biodegradable polyolefins. Prog. Polym. Sci. 36, 1015-1049.

Andrady, A.L., 2011. Microplastics in the marine environment. Mar. pollut. bull. 62, pp. 1596-1605.

Andrady, A.L., Neal, M.A., 2009. Applications and societal benefits of plastics. Philos. Trans. R. Soc. B. 364 (1526), 1977-1984.

Anuar Sharuddin, S.D., Abnisa, F., Wan Daud, W.M.A., Aroua, M.K., 2016. A review on pyrolysis of plastic wastes. Energy Convers. Manage. 115, 308-326. 
Asakura, H., Matsuto, T., Tanaka, N., 2004. Behavior of endocrine-disrupting chemicals in leachate from MWS landfill sites in Japan. Waste Manage. 24, 613-622.

ASM International, 2003. Thermal analysis and thermal properties, Characterization and failure analysis of plastics. Steve Lampman (Ed.), USA, pp. 115-117.

Aznar, M.P., Caballero, M.A., Sancho, J.A., Francés, E., 2006. Plastic waste elimination by co-gasification with coal and biomass in fluidized bed with air in pilot plant. Fuel Process. Technol. 87 (5), 409-420.

Bauer, M.J., Herrmann, R., 1998. Dissolved organic carbon as the main carrier of phthalic acid esters in municipal landfill leachates. Waste Manage. Res. 16 (5), 446-454.

Beißmann, S., Stiftinger, M., Grabmayer, K., Wallner, G., Nitsche, D., Buchberger, W., 2013. Monitoring the degradation of stabilization systems in polypropylene during accelerated aging tests by liquid chromatography combined with atmospheric pressure chemical ionization mass spectrometry. Polym. Degrad. Stab. 98, 1655-1661.

Bhalla, B., Saini, M.S., Jha, M.K., 2017. Characterization of leachate from municipal solid waste (MSW) landfilling sites of Ludhiana, India: a comparative study. Int. J. Eng. Res. Appl. (IJERA). 2 (6), 732-745.

Bhatnagar, A., Kaczala, F., Burlakovs, J., Kriipsalu, M., Hogland, M., Hogland, W., 2017. Hunting for valuables from landfills and assessing their market opportunities A case study with Kudjape landfill in Estonia. Waste Manage. Res. 35 (6), 627-635.

Björn, A., Hörsing, M., Karlsson, A., Mersiowsky, I., Ejlertsson, J., 2007. Impacts of temperature on the leaching of organotin compounds from poly(vinyl chloride) plastics-a study conducted under simulated landfill conditions. J. Vinyl Addit. Technol. 13, 176-188. 
Bosmans, A., De Dobbelaere, C., Helsen, L., 2014. Pyrolysis characteristics of excavated waste material processed into refuse derived fuel. Fuel. 122, 198-205.

Bosmans, A., Vanderreydt, I., Geysen, D., Helsen, L., 2013. The crucial role of Waste-toEnergy technologies in enhanced landfill mining: A technology review. J. Clean. Prod. 55, $10-23$.

Breyer, S., Mekhitarian, L., Rimez, B., Haut, B., 2017. Production of an alternative fuel by the co-pyrolysis of landfill recovered plastic wastes and used lubrication oils. Waste Manage. 60, 363-374.

Brydson, J.A., 1999. Plastic materials. 7th edn. Oxford: Butterworth-Heinemann.

Caballero, B.M., de Marco, I., Adrados, A., López-Urionabarrenechea, A., Solar, J., Gastelu, N., 2016. Possibilities and limits of pyrolysis for recycling plastic rich waste streams rejected from phones recycling plants. Waste Manage. 57, 226-234.

CCOHS Canadian Centre for Occupational Health \& Safety, 2012. CCHS Chemical Name: Hydrogen Sulfide. http://www.ccohs.ca/products/databases/samples/cheminfo.html (accessed 05.05.17).

Chen, D., Yin, L., Wang, H., He, P., 2015. Reprint of: Pyrolysis technologies for municipal solid waste: A review. Waste Manage. 37, 116-136.

Chiemchaisri, C., Charnnok, B., Visvanathan, C., 2010. Recovery of plastic wastes from dumpsite as refuse-derived fuel and its utilization in small gasification system. Bioresour. Technol. 101(5), 1522-1527.

Cossu, R., Raga, R., Rossetti, D., 2003. The PAF model: an integrated approach for landfill sustainability. Waste Manage. 23, 37-44. 
Datta, J., Kopczyńska, P., 2016. From polymer waste to potential main industrial products: Actual state of recycling and recovering. Crit. Rev. Environ. Sci. Technol. 46, 905-946.

Dewil, R., Everaert, K., Baeyens, J., 2006. The European plastic waste issue: trends and toppers in its sustainable re-use. Proceedings of the 17th International Congress of Chemical and Process Engineering, 27-31 August 2006, Prague, Czech Republic.

Eckford, R.E., Fedorak, P.M., 2002. Planktonic nitrate-reducing bacteria and sulfate-reducing bacteria in some Western Canadian oil field waters. J. Ind. Microbiol. Biotechnol. 29, 8392.

Ejlertsson, E., Karlsson, A., Lagerkvist, A., Hjertberg, T., Svensson, B.H., 2003. Effects of co-disposal of wastes containing organic pollutants with municipal solid waste-a landfill simulation study. Adv. Environ. Res. 7, 949-960.

El-Fadel, M., Bou-Zeid, E., Chahine, W., Alayli, B., 2002. Temporal variation of leachate quality from pre-sorted and baled municipal solid waste with high organic and moisture content. Waste Manage. 22 (3), 269-282.

EURELCO, 2017. European Parliament votes YES to include ELFM in the EU Landfill Directive. https://www.eurelco.org/single-post/2017/03/15/European-Parliament-votesYES-to-include-Enhanced-Landfill-Mining-in-the-EU-Landfill-Directive (accessed 05.05.17).

European Commission, 2016. Directive 2008/98/EC of waste (Waste Framework Directive). http://ec.europa.eu/environment/waste/framework/ (accessed 15.05.17).

European Commission, 2017. Critical raw material closed loop recovery. https://ec.europa.eu/growth/tools-databases/eip-raw-materials/en/content/critical-rawmaterial-closed-loop-recovery (accessed 15.05.17). 
European Parliament, 2009. Appendix XVII REACH. no. 552/2009. Eur. Union Official J. $164,7-31$.

European Parliament. Council of the European Union, 1999. Council Directive 1999/31/EC of 26 April 1999 on the landfill of waste.

European Parliament. Council of the European Union, 2008. Directive 2008/98/EC of the European Parliament and of the Council of 19 November 2008 on waste and repealing certain Directives.

European Parliament. Council of the European Union, 2015. Proposal for a DIRECTIVE OF THE EUROPEAN PARLIAMENT AND OF THE COUNCIL amending Directive 1999/31/EC on the landfill of waste.

Eurostat, 2016. Municipal waste generation and treatment, by type of treatment method. http://ec.europa.eu/eurostat/tgm/table.do?tab=table\&plugin=1\&language=en $\& p c o d e=t s d p c$ 240 (accessed 15.05.17).

Folarin, O.M., Sadiku, E.R., 2011. Thermal stabilizers for poly(vinyl chloride): A review. Int. J. Phys. Sci. 6(18), 4323-4330.

García, J., Davies, S., Villa, R., Gomes, D.M., Coulon, F., Wagland, S.T. 2016. Compositional analysis of excavated landfill samples and the determination of residual biogas potential of the organic fraction. Waste Manage. 55, 336-344.

Gewert, B., Plassmann, M.M., Macleod, M., 2015. Pathways for degradation of plastic polymers floating in the marine environment. Environ. Sci.: Process. Impacts. 17, 15131521.

Gijsman, P., 2008. Review on the thermos-oxidative degradation of polymers during processing and in service. e-Polym. 065, 1-34. 
Gijsman, P., Meijers, G., Vitarelli, G., 1999. Comparison of the UV-degradation chemistry of polypropylene, polyethylene, polyamide 6 and polybutylene terephthalate. Polym. Degrad. Stab. 65, 433-441.

Gilbert, M., 2017. States of Aggregation in Polymers, in: Brydson's Plastics Materials. Elsevier, pp. 39-57.

Grammelis, P., Basinas, P., Malliopoulou, A., Sakellaropoulos, G., 2009. Pyrolysis kinetics and combustion characteristics of waste recovered fuels. Fuel. 88(1), 195-205.

Greedy, D., 2016. Landfilling and landfill mining. Waste Manage. Res. 34, 1-2.

Gutiérrez-Gutiérrez, S.C., Coulon, F., Jiang, Y., Wagland, S., 2015. Rare earth elements and critical metal content of extracted landfilled material and potential recovery opportunities. Waste Manage. 42, 128-136.

Hahladakis, J.N., Velis, C.A., Weber, R., Iacovidou, E., Purnell, P., 2018. An overview of chemical additives present in plastics: Migration, release, fate and environmental impact during their use, disposal and recycling. J. hazard. mater. 344, 179-199.

Hogland, W., Hogland, M., Marques, M., 2011. Enhanced Landfill Mining: Material recovery, energy utilisation and economics in the EU (Directive) perspective. Sustainable Solid Waste Management in Eastern Europe - Prospects for the Future, 19-20 May, Ukraine.

Hogland, W., Marques, M., Nimmermark, S., 2004. Landfill mining and waste characterization: a strategy for remediation of contaminated areas. J. Mater. Cycle Waste Manage. 6, 119-124.Ikada E., 1999. Electron microscope observation of biodegradation of polymers. J. Environ. Polym. Degrad. 7, 197-201. 
Jasso-Gastinel, C.F., Soltero-Martínez, J.F.A., Mendizábal, E., 2017. Introduction:

Modifiable Characteristics and Applications, in: Jasso-Gastinel, C.F., Kenny, J.M. (Eds.), Modification of Polymer Properties. William Andrew, Oxford, pp. 1-21.

Johansson, N., Krook, J., Frändegård, P., 2017. A new dawn for buried garbage? An investigation of the marketability of previously disposed shredder waste. Waste Manage. 60, 417-427.

Jones, P.T., Geysen, D., Tielemans, Y., Van Passel, S., Pontikes, Y., Blanpain, B., Quaghebeur, M., Hoekstra, N. 2013. Enhanced Landfill Mining in view of multiple resource recovery: A critical review. J. Clean. Prod. 55, 45-55.

Jones, P.T., Geysen, D., Tielemans, Y., Pontikes, Y., Blanpain, B., Mishra, B., Apelian, D., 2012. Closing material loops: The enhanced landfill mining concept. J. Miner. Met. Mater. Soc. $64,743-744$.

Ko, J.H., Xu, Q., Jang, Y.C., 2015. Emissions and Control of Hydrogen Sulfide at Landfills: A Review. Crit. Rev. Environ. Sci. Technol. 45, 2043-2083.

Korai, M.S., Mahar, R.B., Uqaili, M.A., 2016. Optimization of waste to energy routes through biochemical and thermochemical treatment options of municipal solid waste in Hyderabad, Pakistan. Energy Convers. Manage. 124, 333-343.

Krook, J., Svensson, N., Eklund, M., 2012. Landfill mining: A critical review of two decades of research. Waste Manage. 32, 513-520.

Kumar, S., Panda, A.K., Singh, R.K., 2011. A review on tertiary recycling of high-density polyethylene to fuel. Resour. Conserv. Recycl. 55(11), 893-910.

Kunwar, B., Cheng, H.N., Chandrashekaran, S.R., Sharma, B.K., 2016. Plastics to fuel: a review. Renew. Sustain. Energy Rev. 54, 421-428. 
Lampman, S., 2003. Characterization and failure analysis of plastics. ASM International.

Lettieri, P., Al-Salem, S., 2011. Thermochemical treatment of plastic solid waste, in: Letcher, T.M., Vallero, D. (Eds.), Waste: a Handbook for Management. Elsevier, pp. 233-242.

Lopez, G., Artetxe, M., Amutio, M., Bilbao, J., Olazar, M., 2017. Thermochemical routes for the valorization of waste polyolefinic plastics to produce fuels and chemicals. A review. Renew. Sustain. Energy Rev. 73, 346-368.

Lovley, D. R., 1991. Dissimilatory Fe (III) and Mn (IV) Reduction. Microbiol. Rev. 55, 259287.

Masoumi, H., Safavi, S.M., Khani, Z., 2012. Identification and classification of plastic resins using near infrared, reflectance spectroscopy. Int. J. Mech. Ind. Eng. 6, 877-884.

Mastellone, M.L., 1999. Thermal treatments of plastic wastes by means of fluidized bed reactors. PhD thesis, Department of Chemical Engineering, Second University of Naples, Italy.

McKeen, L.W., 2014. Effect of Temperature and other Factors on Plastics and Elastomers, third ed. Elsevier.

Miandad, R., Barakat, M.A., Aburiazaiza, A.S., Rehan, M., Nizami, A.S., 2016. Catalytic pyrolysis of plastic waste: A review. Process. Saf. and Environ. Prot. 102, 822-838.

Miandad, R., Barakat, M.A., Aburiazaiza, A.S., Rehan, M., Ismail, I.M.I., Nizami, A.S., 2017. Effect of plastic waste types on pyrolysis liquid oil. Int. Biodeter. Biodegr. 119, 239252.

Muenmee, S., Chiemchaisri, W., Chiemchaisri, C., 2016. Enhancement of biodegradation of plastic wastes via methane oxidation in semi-aerobic landfill. Int. Biodeter. Biodegr. 113, 244-255. 
Müller, R.J., Kleeberg, I., Deckwer, W.D., 2001. Biodegradation of polyesters containing aromatic constituents. J. Biotechnol. 86, 87-95.

Münnich, K., Wanka, S., Zeiner, A., Fricke, K., 2015. Landfill mining - recovery and re-use of the final material. 15th International Waste Management and Landfill Symposium, Sardinia 2015.

PlasticsEurope, 2016. Plastics - the Facts 2016: An Analysis of European Plastics Production, Demand and Waste Data. http://www.plasticseurope.org/Document/plastics---the-facts2016-15787.aspx?FolID=2 (accessed 6.04. 2017).

Pospisil, J., Nespurek, S., 1997. Highlights in chemistry and physics of polymer stabilization. Macromol. Symp. 115, 143-63.

Prechthai, T., Padmasri, M., Visvanathan, C., 2008. Quality assessment of mined MSW from an open dumpsite for recycling potential. Resour. Conserv. Recycl. 53, 70-78.

Prudent, P., Domeizel, M., Massiani, C., 1996. Chemical sequential extraction as decisionmaking tool: Application to municipal solid waste and its individual constituents. Sci. Total. Environ. 178, 55-61.

Quaghebeur, M., Laenen, B., Geysen, D., Nielsen, P., Pontikes, Y., Van Gerven, T., Spooren, J., 2013. Characterization of landfilled materials: Screening of the enhanced landfill mining potential. J. Clean. Prod. 55, 72-83.

Rotheut, M., Quicker, P., 2017. Energetic utilisation of refuse derived fuels from landfill mining. Waste Manage. 62, 101-117.

Ruj, B., Pandey, V., Jash, P., Srivastava, V.K., 2015. Sorting of plastic waste for effective recycling. Int. J. Appl. Sci. Eng. Res. 4 (4), 564-571. 
Saikia, N., de Brito, J., 2012. Use of plastic waste as aggregate in cement mortar and concrete preparation: A review. Constr. Build. Mater. 34, 385-401.

Santaweesuk, C., Janyalertadun, A., 2017. The production of fuel oil by conventional slow pyrolysis using plastic waste from a municipal landfill. Int. J. Environ. Sci. Devel. 8 (3), $168-173$.

Saquing, J.M., Saquing, C.D., Knappe, D.R.U., Barlaz, M.A., 2010. Impact of plastics on fate and transport of organic contaminants in landfills. Environ. Sci. Technol. 44(16), 63966402.

Savage, G.M., Gouleke, C.G., Stein, E.L., 1993. Landfill mining: past and present. BioCycle. $34(5), 58-62$.

Scott, G.M., 2002. Degradable polymers principles and applications, Springer, Netherlands, Dordrecht.

Sel, İ., Çakmakcı, M., Özkaya, B., Suphi Altan, H. 2016. Case study on prediction of remaining methane potential of landfilled municipal solid waste by statistical analysis of waste composition data. Waste Manage. 56, 310-317.

Shah, A.A., Hasan, F., Hameed, A., Ahmed, S., 2008. Biological degradation of plastics: A comprehensive review. Biotechnol. Adv. 26 (3), 246-265.

Sharma, B.K., Moser, B.R, Vermillion, K.E., Doll, K.M., Rajagopalan, N., 2014. Production, characterization and fuel properties of alternative diesel fuel from pyrolysis of waste plastic grocery bags. Fuel Process. Technol. 122, 79-90.

Sharma, R., Bansal, P.P., 2016. Use of different forms of waste plastic in concrete - A review. J. Clean. Prod. 112, 473-482. 
Singh, R.K., Ruj, B., 2016. Time and temperature depended fuel gas generation from pyrolysis of real world municipal plastic waste. Fuel. 174, 164-171.

Sørum, L., Grønli, M.G., Hustad, J.E., 2001. Pyrolysis characteristics and kinetics of municipal solid wastes. Fuel. 80, 1217-1227.

Substances and Technologies (SubsTech), 2013. Plastic recycling. http://www.substech.com/dokuwiki/doku.php?id=plastics_recycling\#mechanical_recyclin $\mathrm{g}$ (accessed 05.05.17).

Ted Pella Inc., 2017. Chemical Resistances of Plastics.

https://www.tedpella.com/company_html/PlasticsChemResistance.htm (accessed: 16.12.16)

Teuten, E.L., Saquing, J.M., Knappe, D.R.U., Barlaz, M.A., Jonsson, S., Björn, A., Rowland, S.J., Thompson, R.C., Galloway, T.S., Yamashita, R., Ochi, D., Watanuki, Y., Moore, C., Viet, P.H., Tana, T.S., Prudente, M., Boonyatumanond, R., Zakaria, M.P., Akkhavong, K., Ogata, Y., Hirai, H., Iwasa, S., Mizukawa, K., Hagino, Y., Imamura, A., Saha, M., Takada, H., 2009. Transport and release of chemicals from plastics to the environment and to wildlife. Philos. Trans. R. Soc. B. Biol. Sci. 364, 2027-2045.

Thompson, R.C., Moore, C.J., Saal, F.S.V., Swan, S.H., 2009. Plastics, the environment and human health: Current consensus and future trends. Philos. Trans. R. Soc. B. Biol. Sci. 364 (1526), 2153-2166.

Tielemans, Y., Laevers, P., 2010. Closing the Circle, an Enhanced Landfill Mining case study. 1st Int. Symposium on Enhanced Landfill Mining, Houthalen-Helchteren, 4-6 December 2010. 
Tsuchida, D., Kajihara, Y., Shimidzu, N., Hamamura, K., Nagase, M., 2011. Hydrogen sulfide production by sulfate-reducing bacteria utilizing additives eluted from plastic resins. Waste Manage. Res. 29, 594-601.

Urase, T., Okumura, H., Panyosaranya, S., Inamura, A., 2008. Emission of volatile organic compounds from solid waste disposal sites and importance of heat management. Waste Manage. Res. 26, 534-538.

Van Passel, S., Dubois, M., Eyckmans, J., De Gheldere, S., Ang, F., Jones, P.T., Van Acker, K., 2013. The economics of enhanced landfill mining: private and societal performance drivers. J. Clean. Prod. 55, 92-102.

Van Vossen, W.J., Prent, O.J., 2011. Feasibility study - Sustainable material and energy recovery from landfills in Europe. 13th International Waste Management and Landfill Symposium, Sardinia 2011.

Vasile, C., 2005. Practical guide to polyethylene. RAPRA technology, Shrewsbury.

Venkatachalam, S., Nayak, S.G., Labde, J. V., Gharal, P.R., Rao, K., Kelkar, A.K., 2012. Degradation and Recyclability of Poly (Ethylene Terephthalate), in Saleh, H.E.D. (Ed.) Polyester. InTech. https://www.intechopen.com/books/polyester/degradation-andrecyclability-of-poly-ethylene-terephthalate (accessed 25.05.17).

Ventosa, I.P., Forn, M.C., Sora, M.J., 2014 Urban mining extracting resources from landfill sites. Segur Med Amb N134.

VERC, 2001. Deliverable Report. Virtual European Recycling Centre VERC, GTC1-200143018. 
Vrancken, C., Longhurst, P.J., Wagland, S.T., 2017. Critical review of real-time methods for solid waste characterisation: Informing material recovery and fuel production. Waste Manage. 61, 40-57.

Webb, H.K., Arnott, J., Crawford, R.J., Ivanova, E.P., 2013. Plastic degradation and its environmental implications with special reference to poly(ethylene terephthalate). Polym. $5,1-18$

Wienaah, MM., 2007. Sustainable plastic waste management - A case of Accra, Ghana. MSc thesis. Stockholm.

Wolfsberger, T., Aldrian, A., Sarc, R., Hermann, R., Höllen, D., Budischowsky, A., Zöscher, A., Ragoßnig, A., Pomberger, R. 2015. Landfill mining: Resource potential of Austrian landfills - Evaluation and quality assessment of recovered municipal solid waste by chemical analyses. Waste Manage. Res. 33 (11), 962-974.

Wong, S.L., Ngadi, N., Abdullah, T.A.T., Inuwa, I.M., 2016. Current state and future prospects of plastic waste as source of fuel: A review. Renew. Sustain. Energy Rev. 50, $1167-1180$.

Xu, S.Y., Zhang, H., He, P.J., Shao, L.M., 2011. Leaching behaviour of bisphenol A from municipal solid waste under landfill environment. Environ. Technol. 32, 1269-1277.

Yang, K., Xu, Q., Townsend, T.G., Chadik, P., Bitton, G., Booth, M., 2006. Hydrogen sulfide generation in simulated construction and demolition debris landfills: Impact of waste composition. J. Air Waste Manage. Assoc. 56(8), 1130-1138.

Yang, Q., Chen, X., He, Z., Lan, F., Liu, H., 2016. The glass transition temperature measurements of polyethylene: Determined by using molecular dynamic method. RSC Adv. 6(15), 12053-12060. 
Yassin, L., Lettierim, P., Simons, S.J.R., Germana, A., 2005. Energy recovery from thermal processing of waste: a review. Eng. Sustain. 158, 97-103.

Younan, Y., van Goethem, M.W.M., Stefanidis, G.D., 2016. A particle scale model for municipal solid waste and refuse-derived fuels pyrolysis. Comput. Chem. Eng. 86, 148159.

Zheng, Y., Yanful, E.K., Bassi, A.S., 2005. A review of plastic waste biodegradation. Crit. Rev. Biotechnol. 25, 243-250.

Zhou, C., Fang, W., Xu, W., Cao, A., Wang, R., 2014. Characteristics and the recovery potential of plastic wastes obtained from landfill mining. J. Clean. Prod. 80, 80-86.

Zia, K.M., Bhatti, H.N., Ahmad Bhatti, I., 2007. Methods for polyurethane and polyurethane composites, recycling and recovery: A review. React. Funct. Polym. 67 (8), 675-692. 


\section{List of captions}

Fig. 1. General polymer auto-oxidation process.

Fig. 2. Tertiary recycling techniques (adapted from Zia et al., 2007; Al-Salem et al., 2009).

Table 1. Degradation processes and degradation products for common plastics (adapted from Gewert et al., 2015; Venkatachalam, 2012).

Table 2. Plastic corrosion behaviour in the presence of $\mathrm{H}_{2} \mathrm{~S}$ (Pruett, 2000, Pruett, 1994, Schweitzer, 1995 cited in CCOHS, 2012).

Table 3. General characteristics of leachate at different age (adapted from Bhalla et al., 2012).

Table 4. Leachate chemicals and related plastics affected (adapted from El-Fadel et al., 2002; Ted Pella Inc., 2017).

Table 5. Chemical characteristics of excavated plastic according to years of storage.

Table 6. Chemical characteristics of excavated plastics.

Table 7. Sorting technique for plastic waste.

Table 8. Pyrolysis process categories (adapted from Bosmans et al., 2013). 